\title{
HEMATOLOGI AYAM KAMPUNG SUPER YANG DIBERI MINYAK KELAPA SAWIT TERPROTEKSI DALAM RANSUM
}

\author{
Nur Aenih ${ }^{1}$, Muhammad Amrullah Pagala ${ }^{2}$, Andi Murlina Tasse ${ }^{2}$ \\ ${ }^{1}$ Mahasiswa Fakultas Peternakan Universitas Halu Oleo, Kendari \\ ${ }^{2}$ Dosen Fakultas Peternakan Universitas Halu Oleo, Kendari \\ *e-mail : amroe74@gmail.com
}

\begin{abstract}
ABSTRAK
Tujuan penelitian adalah untuk mempelajari hematologi ayam kampung super yang diberi minyak kelapa sawit terproteksi dalam ransum. Materi yang digunakan dalam penelitian ini adalah 64 ekor ayam kampong super yang tidak dibedakan jenis kelaminnya yang dipelihara sampai umur 5 minggu. Penelitian terdiri dari 4 perlakuan dan 4 ulangan dan setiap ulangan terdiri dari 4 ekor ayam. Minyak kelapa sawit terproteksi digunakan pada level 0\% (P0), 3\%(P1), 6\% (P2), dan 9\% (P3). Parameter yang diamati adalah jumlah eritrosit, kadar hemoglobin, dan jumlah leukosit. Penelitian menggunakan percobaan dengan Rancangan Acak Kelompok (RAK) apabila terdapat perbedaan perlakuan maka dilanjutkan Uji Berganda Duncan. Hasil penelitian menyimpulkan bahwa minyak kelapa sawit terproteksi tidak memberikan perbedaan yang nyata terhadap jumlah eritrosit, kadar hemoglobin, dan jumlah leukosit. Disarankan agar melakukan kajian lebih lanjut mengenai minyak kelapa sawit terproteksi.
\end{abstract}

Kata kunci: Hematologi, Ayam kampung super, Minyak kelapa sawit terproteksi

\begin{abstract}
The purpose of the research is to study Hematology free-range chicken super given palm oil in the protected rations. Material used in this study was 64 super chicken tail that does not distinguish in the sex in the keep until 5 weeks. Research consists of 4 treatments and 4 Deuteronomy and per Deuteronomy consists of 4 chickens. Palm oil protected in use at level $0 \%(\mathrm{P} 0), 3 \%(\mathrm{P} 1), 6 \%(\mathrm{P} 2)$ and 9\% (P3). Parameter that is observed is the number of erythrocytes. Haemoglobin levels and the amount of leukocytes. Research using experimental design with random group (RAK) if there is a difference in treatment continue double test Duncan. Research results concluded that the protected palm oil does not give a real difference against the number of erythrocytes, Haemoglobin levels, and the number of leukocytes. It is recommended that further studies regarding the protected palm oil.
\end{abstract}

Keywords : Hematology, Super chicken, Palm oil protected

\footnotetext{
${ }^{*}$ Corresponding author
} 


\section{PENDAHULUAN}

Ayam kampung super merupakan ayam hasil persilangan antara ayam kampung dengan ayam ras jenis petelur. Ayam hasil persilangan tersebut memiliki pertumbuhan lebih cepat dibanding ayam kampung lokal. Budidaya ayam kampung super saat ini mulai banyak diminati oleh peternak karena lebih menguntungkan dapat dipanen dalam waktu yang lebih singkat, pemeliharaa $\pm 2,5 \mathrm{n}$ bulan sudah dapat dipanen dengan bobot rata-rata mencapai 1,5 kg (Salim, 2013).

Peningkatan produktivitas ayam kampung super dapat dilakukan melalui perbaikan kuantitas dan kualitas pakan, pakan berkualitas harus mengandung zat zat nutrisi yang dibutuhkan sesuai dengan perkembangan umur dan tujuan pemeliharaan. Pakan yang sempurna dengan kandungan zat-zat nutrisi yang seimbang akan memberikan hasil yang optimal. Zat-zat nutrisi yang diperlukan diantaranya protein dan energi.

Salah satu bahan yang sering dimanfaatkan sebagai sumber energi adalah minyak kelapa sawit, namun demikian penggunaan minyak kelapa sawit sebagai pakan mempunyai kendala seperti sulit dicampur dengan pakan lain terutama dalam konsentrat sehingga diperlukan pengolahan sebelum digunakan sebagai pakan. Teknologi pengolahan pakan pada minyak kelapa sawit yang sering dilakukan adalah teknik hidrolisis.

Salah satu produk hidrolisis minyak adalah campuran garam karboksilat kering (CGKK). Beberapa hasil penelitian telah dilaporkan, diantaranya bahwa penambahan CGKK sebagai sumber energi dapat meningkatkan performa pada ternak kerbau dan sapi sebagai akibat dari proses metabolisme dalam tubuh ternak yang berlangsung lebih efisien. Proses metabolisme ini berkaitan erat dengan profil darah pada ternak.

Darah berfungsi sebagai pengangkut oksigen dan sebagai media trasportasi zat zat makanan, apabila proses metabolisme dalam tubuh ternak tidak efisien maka akan menurunkan jumlah eritrosit dan kadar hemoglobin, dan jumlah leukosit meningkat. Profil hematologi darah dapat diukur melalui status metabolisme dan juga dapat ukur melalui jumlah eritrosit, kadar hemoglobin, dan jumlah leukosit.

Meskipun penelitian mengenai penggunaan minyak kelapa sawit sebagai pakan pada ternak dan sumber energi ternak secara umum telah banyak dilakukan, namun penggunaannya pada ayam khususnya ayam kampung super belum banyak dilakukan. Oleh karena itu, perlu dilakukan penelitian mengenai pengaruh minyak kelapa sawit sebagai pakan terhadap profil hematologi ayam kampung super.

\section{MATERI DAN METODE}

\section{Waktu dan Tempat}

Penelitian dilaksanakan pada bulan Januari sampai dengan Februauri 2016 bertempat di Laboratorium Lapang Kandang Pembibitan Unggas Fakultas peternakan UHO.

\section{Materi}

Penelitiam menggunakan 64 ekor ayam kampung super. Kandang yang digunakan dalam penelitian adalah 
kandang litter terbagi menjadi 16 petak tiap kandang berisi 4 ekor ayam yang dilengkapi lampu, tempat pakan dan minum.

\section{Metode}

Metode yang digunakan adalah percobaan lapang dengan menggunakan Rancangan Acak Kelompok (RAK) terdiri dari 4 perlakuan dan 4 ulangan, dimana setiap ulangan terdiri dari 4 ekor ayam. Data yang dihasilkan akan dianalisa menggunakan analisis ragam, apabila terdapat perbedaan perlakuan dilanjutkan dengan Uji Jarak Berganda Duncan. Adapun level perlakuan yaitu P0 (tanpa penambahan minyak kelapa sawit terproteksi), P1 (penambahan 3\% minyak kelapa sawit terproteksi), P2 (penambahan 6\% minyak kelapa sawit terproteksi) dan P3 (penambahan 9\% minyak kelapa sawit terproteksi).
Variabel penelitian yang diukur adalah: jumlah eritrosit, kadar hemoglobin, dan jumlah leukosit yang nantinya akan dianalisis menggunakan hematology analyzer Rayto RT-7600.

Pengambilan sampel dara ayam dilakukan pada umur 5 minggu dalam setiap kelompok perlakuan. Sampel darah diambil dari bagian vena Axillaris (pada sayap) sebanyak $3 \mathrm{ml}$ dengan menggunakan syringe yang kemudian dimasukaan kedalam tabung vacumtainer yang mengandung antokoagulasi Ethylene Diamine Tetra Acid (EDTA).

\section{HASIL DAN PEMBAHASAN}

\section{A. Jumlah Eritrosit}

Rataan jumlah eritrosit pada penelitian ayam kampung super yang diberi minyak kelapa sawit terproteksi dalam ransum disajikan pada Tabel 2.

Tabel 2. Rataan Jumlah Eritrosit dalam Darah Ayam Kampurg Super $\left(10^{6} / \mathrm{mm}^{3}\right)$

\begin{tabular}{cccccc}
\hline Kelompok & $\begin{array}{c}\text { Perlakuan } \\
\text { P0 }\end{array}$ & P1 & P2 & P3 & Rataan \\
& $(0 \%)$ & $(3 \%)$ & $(6 \%)$ & $(9 \%)$ & \\
\hline I & 4,3 & 2,59 & 0,63 & 0,4 & 1,78 \\
II & 0,81 & 1,91 & 1,23 & 0,25 & 1,24 \\
III & 2,5 & 0,86 & 1,15 & 0,15 & 1,53 \\
IV & 1,73 & 0,91 & 0,73 & 0,11 & 1,49 \\
Rataan & $2,34^{\mathrm{a}}$ & $1,56^{\mathrm{ab}}$ & $0,93^{\mathrm{b}}$ & $0,22^{\mathrm{c}}$ & \\
\hline
\end{tabular}

Keterangan: Superskrip yang berbeda pada baris yang sama menunjukan pengaruh antar perlakuan berbeda nyata $(\mathrm{P}<0,05)$

Berdasarkan data Tabel 2 menunjukan bahwa penambahan Minyak Kelapa Sawit terproteksi (MKST) 0\%, $3 \%$, 6\%, dan $9 \%$ dalam ransum memberikan hasil rataan jumlah eritrosit ayam berkisar antara $0,22-2,34 \times 10^{6} / \mathrm{mm}^{3}$. Kisaran tertinggi terdapat pada kontrol perlakuan P0 $\left(2,34 \times 10^{6} / \mathrm{mm}^{3}\right)$ dan terendah terdapat pada P3 $(0,22$ $\left.\mathrm{x} 10^{6} / \mathrm{mm}^{3}\right)$.

Kisaran rataan jumlah eritrosit yang diperoleh dalam penelitian lebih rendah dari kisaran normal. Darmawan (2002) mengemukakan bahwa kisaran normal jumlah eritrosit dalam darah ayam berada pada kisaran 2,3 $-3,5 \times 10^{6} / \mathrm{mm}^{3}$. 
Rendahnya jumlah eritrosit dalam darah ayam disebabkan pengambilan sampel darah dilakukan pada ayam umur 5 minggu masi dalam periode pertumbuhan. Umur ayam yang belum dewasa menyebabkan jumlah eritrosit yang diperoleh rendah. Hal ini sejalan dengan pendapat Ganong (2008) yang menyatakan bahwa jumlah eritrosit dipengaruhi oleh umur, dan jenis kelamin. Semakin dewasa umur ayam maka jumlah eritrositnya semakin meningkat. Penyebab lain rendahnya jumlah eritrosit ayam pada penelitian ini adalah ayam diduga dalam keadaan hipoksia (kekurangan oksigen), kondisi ini akan mempengaruhi pembentukan eritrosit. Hal ini disebabkan penelitian dilakukan bertepatan dengan awal musim hujan sehingga keadaan kandang dalam kondisi tertutup terpal sepanjang hari. Kondisi ini menyebabkan ayam kekurangan oksigen yang mempengaruhi pembentukan eritrosit.

Hasil analisis ragam menunjukan bahwa penambahan MKST 0\%, 3\%, 6\% dan $9 \%$ dalam ransum memberikan pengaruh yang nyata $(\mathrm{P}<0,05)$ terhadap jumlah eritrosit. Sebaliknya pada kelompok I-IV tidak memberikan pengaruh nyata $(\mathrm{P}>0,05)$ terhadap jumlah eritrosit. Hasil analisis uji lanjut menunjukan bahwa penambahan MKST $0 \%$ berbeda nyata dengan perlakuan MKST $6 \%$ dan 9\%, tetapi tidak berbeda nyata dengan penambahan MKST 3\%.

\section{B. Kadar Hemoglobin}

Rataan kadar hemoglobin pada penelitian ayam kampung super yang diberi minyak kelapa sawit terproteksi dalam ransum disajikan pada Tabel 3.

Tabel 3. Rataan Kadar Hemoglobin (g/100)

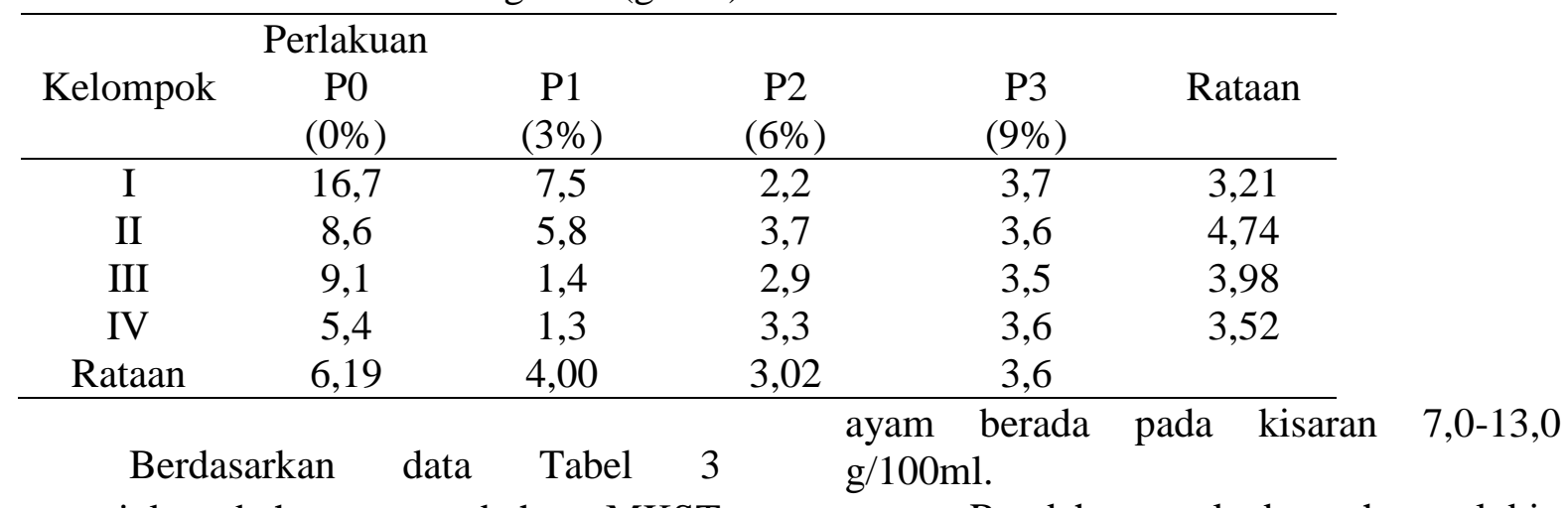

menunjukan bahwa penambahan MKST $0 \%, 3 \%, 6 \%$, dan $9 \%$ dalam ransum memberikan hasil rataan kadar hemoglobin ayam berkisar antara 3,02$6,19 \mathrm{~g} / 100$. Kisaran tertinggi terdapat pada kontrol perlakuan P0 (6,19 g/100 ) dan terendah terdapat pada P2 (3,02 g/100).

Kisaran rataan kadar hemoglobin yang diperoleh dalam penelitian lebih rendah dari kisaran normal. Darmawan (2002) mengemukakan bahwa kisaran normal kadar hemoglobin dalam darah
Rendahnya kadar hemoglobin dalam darah ayam disebabkan karena jumlah eritrosit rendah. Kadar hemoglobin berkorelasi positif dengan jumlah eritrosit. Kondisi kandang yang tertutup terpal sepanjang hari menyebabkan ayam kekurangan oksigen sehingga kadar hemoglobin menurun. Menurut Schalm (2010) kadar hemoglobin dipengaruhi oleh kadar oksigen dan jumlah eritrosit sehingga ada kecenderungan jika jumlah eritrosit rendah, maka kadar hemoglobin akan rendah dan jika oksigen dalam darah rendah, maka tubuh terangsang 
meningkatkan produksi eritrosit dan hemoglobin. Kandungan protein dalam ransum yang rendah menyebabakan penurunan kadar hemoglobin. Menurut Guyton dan Hall (2010) protein, terutama asam amino, glisin, dan mineral $\mathrm{Fe}$ merupakan komponen pembentukan hemoglobin.

Hasil analisis ragam menunjukan bahwa penambahan MKST 0\%, 3\%, 6\% dan $9 \%$ dalam ransum memberikan pengaruh tidak nyata $(\mathrm{P}>0,05)$ terhadap kadar hemoglobin. Sama halnya pada kelompok I-IV tidak berpengaruh nyata $(\mathrm{P}>0,05)$ terhadap kadar hemoglobin.

\section{Jumlah Leukosit}

Rataan jumlah leukosit pada penelitian ayam kampung super yang diberi minyak kelapa sawit terproteksi dalam ransum disajikan pada tabel 4.

Tabel 4. Rata-rata Jumlah Leukosit $\left(10^{3} / \mathrm{mm}^{3}\right)$

\begin{tabular}{cccccc}
\hline Kelompok & $\begin{array}{c}\text { Perlakuan } \\
\text { P0 }\end{array}$ & P1 & P2 & P3 & Rataan \\
& $(0 \%)$ & $(3 \%)$ & $(6 \%)$ & $(9 \%)$ & \\
\hline I & 166,5 & 102,2 & 63 & 55,9 & $77,72^{\mathrm{a}}$ \\
II & 98 & 61,7 & 62,8 & 54,8 & $55,86^{\mathrm{b}}$ \\
III & 107 & 64,8 & 62,6 & 52,4 & $57,96^{\mathrm{b}}$ \\
IV & 76,3 & 65,8 & 57,7 & 50,8 & $50,92^{\mathrm{b}}$ \\
Rataan & $111,95^{\mathrm{a}}$ & $73,625^{\mathrm{b}}$ & $61,525^{\mathrm{bc}}$ & $53,475^{\mathrm{c}}$ & \\
\hline
\end{tabular}

Keterangan: Superskrip yang berbeda pada baris yang sama menunjukan pengaruh antar perlakuan berbeda nyata $(\mathrm{P}<0,05)$

Berdasarkan data Tabel 4 menunjukan bahwa penambahan MKST $0 \%, 3 \%, 6 \%$, dan $9 \%$ dalam ransum memberikan hasil rataan jumlah leukosit ayam berkisar antara 53,475-111,95 $10^{3} / \mathrm{mm}^{3}$. Kisaran tertinggi terdapat pada kontrol perlakuan P0 $\left(111,95 \quad 10^{3} / \mathrm{mm}^{3}\right)$ dan terendah terdapat pada P3 $(53,475$ $10^{3} / \mathrm{mm}^{3}$ )

Kisaran rataan jumlah leukosit yang diperoleh dalam penelitian lebih tinggi dari kisaran normal. Kisaran normal jumlah leukosit dalam darah ayam berada pada kisaran 20.000-30.000/ $\mathrm{mm}^{3}$ (Swenson 1984).

Tingginya jumlah leukosit dalam penelitian ini diduga disebabkan oleh ayam sampel penelitian dalam keadaan stres. Dalam kondisi seperti ini ayam menjadi mudah terinfeksi oleh bibit penyakit. Hal ini sejalan dengan pendapat Rachmawati (2010) dalam kondisi stress terjadi penurunan jumlah eritrosit, nilai hematokrit dan kadar hemoglobin, sedangkan jumlah leukosit cenderung meningkat.

Peningkatan jumlah leukosit menunjukkan bahwa kemampuan tubuh yang tinggi dalam merespon infeksi atau benda asing. Hal ini sesuai dengan pernyataan Soeharsono (2010) bahwa jumlah leukosit yang tinggi menandakan tubuh mampu melawan infeksi.

Hasil analisis ragam menunjukan bahwa penambahan MKST 0\%, 3\%, 6\% dan $9 \%$ dalam ransum memberikan pengaruh yang nyata $(\mathrm{P}<0,05)$ terhadap jumlah leukosit. Hasil uji lanjut menunjukan bahwa perlakuan MKST 0\% berbeda nyata dengan perlakuan MKST 3\%, 6\%, dan 9\%, perlakuan MKST 3\% tidak berbeda nyata dengan perlakuan MKST 6\% tetapi berbeda nyata dengan perlakuan MKST 0\% dan 9\%, perlakuan MKST $6 \%$ tidak berbeda nyata dengan perlakuan MKST 3\% dan $9 \%$ tetapi 
berbeda nyata dengan MKST 0\%, dan perlakuan MKST 9\% tidak berbeda nyata dengan perlakuan MKST $6 \%$ tetapi berbeda nyata dengan perlakuan MKST $0 \%$ dan 3\%. Hasil analisis ragam menunjukan bahwa kelompok I-IV memberikan pengaruh yang nyata $(\mathrm{P}<0,05)$ terhadap jumlah leukosit. Hasil analisis uji lanjut menunjukan bahwa kelompok (I) berbeda nyata dengan kelompok ( II, III, dan IV) tetapi kelompok (II) tidak berbeda nyata dengan kelompok (III dan IV).

\section{KESIMPULAN}

Berdasarkan hasil penelitian dapat disimpulkan bahwa penambahan Minyak Kelapa Sawit Terproteksi (MKST) pada taraf $0 \%$ dapat meningkatakan jumlah leukosit dan kadar hemoglobin, tetapi pada penambahan Minyak Kelapa Sawit Terproteksi (MKST) 3\%, 6\%, dan 9\% dalam ransum tidak dapat meningkatkan jumlah eritrosit, kadar hemoglobin.

\section{DAFTAR PUSTAKA}

Dharmawan, N. S. 2002. Pengantar Patologi Klinik Veteriner (Hematologi Klinik). Pelawasari. Denpasar.

Ganong,W. F. 2008. Buku Ajar Fisiologi Kedokteran (Review of Medical Physicology). Edisi 22. Terjemahan: dr. Brahm U. P. Penerbit Buku Kedokteran EGC, Jakarta.

Ganong, W. F. 1996. Fisiologi Kedokteran. Edisi 17. Jakara. Penerbit Buku Kedokteran EGC.

Guyton, A. C., and J. E. Hall. 2010. Textbook of Medical Physiology. $12^{\text {th }}$ Ed. WB. Saunders Company, Philadelphia.
Guyton, A. C. dan J. E. Hall. 1997. Buku Ajar Fisiologi Kedokteran. Irawati Stiawan, penerjemah, Jakarta: EGC. Terjemahan dari: Texbook of Medical Physiology.

Hanafiah, K. A. 2008. Rancangan Percobaan Teori dan Aplikasi, Edisi ketiga. PT. Raja Grafindo Persada. Jakarta.

Rachmawati, F. 2010. Respon Fisiologi Ikan Nila, Oreochromis niloticus yang Distimulasi dengan Daur Pemuasaan dan Pemberian Pakan Kembali. Seminar Nasional Biologi. Fakultas Biologi UGM. Yogyakarta. Halaman 492-499.

Salim, E. 2013. 45 Hari Siap Panen Ayam Kampung Super. Lily Publisher. Yogyakarta.

Schalm, O.W., N.C. Jain, and E.J. Carol. 2010. Schalm's Veterinary Hematology. 6 Edition. Editor Weiss, D.J. dan K.J. Wardrop. Wiley-Blackwell. Iowa USA.

Soeharsono, L, Andriani E, Hermawan, K. A. Kamil dan A. Mushawwir. 2010. Fisiologi Ternak Fenomena dan Nomena Dasar, Fungsi, dan Interaksi Organ pada Hewan. Widya Padjadjaran, Bandung.

Swenson. 1984. Duke's Phisiology of Domestic Animals. Tenth edition. London. Cornel University Press.

Tasse, A. M., 2010. Tampilan Asam Lemak Dalam Susu Sapi Hasil Pemberian Ransum Mengandung Campuran Garam Karboksilat atau Metil Ester Kering. (Disertasi). Institut Pertanian Bogor. Bogor. 